\title{
Wykorzystanie niestandardowych struktur arytmetycznych w modelowaniu kognitywistycznym myślenia numerycznego ${ }^{1}$
}

\section{Using nonstandard arithmetical structures in cognitive modelling of numerical cognition}

\begin{abstract}
In the paper, we argue, that due to the existence of non-recursive numerical cognition, we cannot arbitrary exclude nonstandard arithmetical structures from the toolset used in cognitive modeling of numerical cognition. We introduce the concept of using nonstandard arithmetical structures in modelling, defend it against the claims and show examples of non-recursive numerical cognition.
\end{abstract}

Keywords: cognitive modeling, numerical cognition, non-recursive numerical cognition, non-standard model of arithmetic, Church-Turing Thesis, Tennenbaum Theorem

W wyniku aksjomatyzacji arytmetyki liczb naturalnych okazało się, że Arytmetyka Peano posiada nie tylko model standardowy z dokładnością do izomorfizmu, ale także nieskończenie wiele modeli niestandardowych. Modele te są nie tylko różne strukturalnie, lecz posiadają całkowicie inne własności metamatematyczne, które od blisko stu lat są przedmiotem badań matematyków. Niestety, wyniki tych badań wydają się całkowicie niedostrzegane przez kognitywistów w ich badaniach nad myśleniem matematycznych. W literaturze przedmiotu rzadko wspomina się o niestandardowych modelach arytmetyki, a jeżeli już, to pojawiają się stanowiska całkowicie wykluczające możliwość wykorzystania niestandardowych struktur arytmetycznych w modelowaniu kognitywistycznym zdolności numerycznych. Jednak argumentacja za taką tezą często nie jest już tak jednoznaczna i zwykle ogranicza się do arbitralnego i lakonicznego stwierdzenia, że „modele niestandardowe są chimerami niekorespondującymi z intuicją" [Dehaene, 1997].

Aby jednoznacznie wykluczyć niestandardowe struktury arytmetyczne jako składowe modeli kompetencji arytmetycznej, można przyjąć dwie strategie. Pierwsza polega na wskazaniu konkretnych wyników empirycznych, wykluczających możli-

1 Praca naukowa finansowana ze środków budżetowych na naukę w latach 2012-2017 jako projekt badawczy nr DI 2011032141 pt. „Nieklasyczne modele kompetencji arytmetycznej” w ramach programu pod nazwą „Diamentowy Grant”. 
wość posługiwania się niestandardowymi strukturami arytmetycznymi w aktywności numerycznej. Strategia ta jest o tyle skomplikowana, że nie da się tego zrobić wprost, ponieważ każda niestandardowa struktura arytmetyczna posiada jako segment początkowy standardową strukturę arytmetyczną. Obrazując to metaforycznie, nawet jeżeli w badanych kontekstach liczymy standardowo, to wciąż możemy operować jedynie wierzchołkiem niestandardowej góry lodowej. Druga strategia polega na wskazaniu pewnych metamatematycznych własności niestandardowych struktur, które, najlepiej na podstawie wyników empirycznych, wykluczą możliwość wykorzystania ich w modelowaniu kognitywistycznym myślenia numerycznego. Podczas gdy pierwsza strategia zakłada pokazanie, że modele niestandardowe "nie są" wykorzystywane, druga strategia polega na pokazaniu, że „nie mogą być” wykorzystane. Doskonałą realizacją tej strategii może być argumentacja wykorzystywana przez strukturalistów obliczeniowych do wskazania standardowych struktur arytmetycznych jako modeli zamierzony Arytmetyki Peano. Argument ten, sformułowany w oparciu o Tezę Churcha-Turinga i Twierdzenie Tennenbauma oraz wykorzystywany w ramach sporu o podstawy matematyki, można z powodzeniem przenieść na grunt kognitywistyki myślenia numerycznego.

$\mathrm{W}$ artykule najpierw przypomnimy podstawowe założenia modelowania kognitywistycznego oraz elementarne informacje o niestandardowych strukturach arytmetycznych. W dalszej części zrekonstruujemy argumentację strukturalistów obliczeniowych, wskazującą model standardowy PA jako jej model zamierzony, na gruncie kognitywistyki myślenia numerycznego, by wreszcie opierając się na bazie eksperymentalnej zagadnienia, wykazać błędność argumentu. Na koniec nakreślimy potencjalne korzyści płynące $\mathrm{z}$ dopuszczenia niestandardowych struktur arytmetycznych jako składowych modeli kognitywistycznych myślenia numerycznego.

\section{Modelowanie kognitywistyczne zdolności numerycznych}

\section{Modele kognitywistyczne}

Jednym z fundamentów kognitywistyki jest założenie, że zjawiska mentalne możemy badać i opisywać w podobny sposób jak zjawiska fizykalne. Umysł jest jednak niezwykle złożoną maszyną obliczeniową, pozwalającą organizmom przetwarzać bodźce ze środowiska, gromadzić wiedzę, a także działać w środowisku. W związku z tym kognitywiści w praktyce badawczej nie formułują ogólnych „praw umysłu”, a raczej starają się zrozumieć działanie jego poszczególnych modułów [Fodor, 1983]. Według Fodora moduły są wyspecjalizowanymi komponentami umysłu, odpowiedzialnymi za przetwarzanie konkretnego typu bodźców (domain specific), które działając niezależnie od siebie (information encapsulation), przetwarzają bodźce w sposób deterministyczny (obligatory firing), w krótkim czasie (fast speed), na podstawie stałej i określonej bazy neuronalnej (fixed neural characteristics). Wśród przykładowych modułów możemy wskazać: moduł odpowiedzialny za motorykę ciała, moduł odpowiedzialny za zdolności muzyczne, moduł odpowiedzialny za akwizycję języka czy wreszcie moduł odpowiedzialny za czynności numeryczne. 
Osiągnięcia kognitywistyki można zatem postrzegać jako zbiór mikroteorii modułów, które będziemy nazywać modelami kognitywistycznymi. Kognitywiści nie wypracowali żadnej definicji ani jednolitej charakterystyki tego, czym jest model. Co więcej, można konstruować modele w ramach różnych od siebie paradygmatów, np. komputacyjnego (Sun, 2008), embodied cognition [Lakoff, Núñez, 2000], dynamicznego czy bayesowskiego.

Możemy jednak porównywać ze sobą konkurencyjne modele, nawet jeżeli są formułowane na gruncie różnych metodologii czy paradygmatów. Będziemy preferować modele silniejsze eksplanacyjnie nad słabszymi, prostsze nad bardziej złożonymi, ogólniejsze nad bardziej partykularnymi, precyzyjniejsze nad zawierającymi wiele „dziur” czy niejasności, potwierdzone eksperymentalnie nad czysto teoretycznymi.

Pomimo istotnych różnic w rozumieniu, czym jest model kognitywistyczny, ponad $80 \%$ artykułów publikowanych w ważnych czasopismach naukowych z zakresu nauk kognitywnych wykorzystuje modelowanie kognitywistyczne [Busemeyer, Diederich, 2010]. W przytoczonych pracach można znaleźć dalsze eksplikacje pojęcia modelu na gruncie konkretnego paradygmatu, a także o wykorzystywanej metodologii.

$\mathrm{Na}$ potrzeby niniejszego artykułu wprowadzamy następującą ogólną eksplikację tego pojęcia:

Model kognitywistyczny to mikroteoria wyspecjalizowanego modułu umysłowego, pozwalająca zinterpretować ogół danych sensorycznych, opisać procesy kognitywne w uogólniony i sformalizowany sposób, a także przewidywać i ingerować $\mathrm{w}$ wyniki procesu.

Przeanalizujmy powyższą eksplikację na przykładzie modelowania kognitywistycznego czynności numerycznych. Naszym celem jest sformułowanie mikroteorii modułu odpowiedzialnego za ogół czynności numerycznych, tj.: tworzenie reprezentacji liczbowych, enumerowanie, estymowanie, przeprowadzanie podstawowych operacji arytmetycznych. Na samym początku formułujemy w ramach modelu pewne założenia co do struktury bodźców numerycznych (np. że możemy podzielić bodźce numeryczne na duże i małe liczby, liczby dokładne i niedokładne, liczby kardynalne i porządkowe). Dalej dopiero w ramach modelu możemy interpretować dane eksperymentalne, a więc reakcje podmiotów kognitywnych na ekspozycję bodźcami numerycznymi. W wyniku tego możemy sformułować ogólne mechanizmy przetwarzania danych wejściowych $\mathrm{w}$ postaci bodźców numerycznych $\mathrm{w}$ dane wyjściowe, czyli wyniki procesu. Rezultaty eksperymentalne pokazują, że nie są to ani pojedyncze, ani proste mechanizmy. Zaczynamy zatem opisywać sposoby tworzenia reprezentacji i mechanizmów mentalnych, w wyniku czego próbujemy rekonstruować proces w sformalizowany sposób, np. w postaci algorytmów, aż do momentu osiągnięcia satysfakcjonującego poziomu ogólności. Poziom ogólności modelu musi być na tyle wysoki, aby pozwalał nam nie tylko na odtworzenie rozmaitych poprawnie przebiegających procesów, ale także na wyjaśnienie tych niepoprawnych, jak dyskalkulia czy sawantyzm. Właściwie już odpowiedź na pytanie „Co to jest dyskalkulia?” wymaga przyjęcia pewnego modelu czynności numerycznych i wskazania zarówno zbieżności, jak i rozbieżności pomiędzy poprawnymi czynnościami numerycznymi a dyskalkulicznymi. 


\section{Silna intensjonalność i niezastępowalność ekstensjonalna modeli kognitywistycznych}

Należy podkreślić, że modele kognitywistyczne dostarczają opisu nie tylko procesów przekształcania danych wejściowych w dane wyjściowe, ale także towarzyszących temu procesowi zjawisk mentalnych. Są one więc czymś zupełnie odmiennym od tego, co nazywa się „teoriami czarnego pudełka”. Zilustrujmy tę metodologię prostym przykładem: załóżmy, że wkładamy gołębia do „pudełka” (dane wejściowe), a następnie w pudełku dokonuje się „hokus-pokus” i wyciągamy królika (dane wyjściowe). Teorie czarnego pudełka pomijają to, co się dzieje w pudełku, i skupiają się jedynie na tym, co trzeba włożyć do pudełka, aby wyciągnąć kota. Jako przykład teorii czarnego pudełka można wskazać wszelkiego rodzaju teorie behawiorystyczne. Tymczasem model kognitywistyczny ma także rekonstruować to, co się dzieje w pudełku, ponieważ dla kognitywistów model o postaci „bodziec $\rightarrow$ hokus-pokus $\rightarrow$ reakcja” ma niewystarczającą moc eksplanacyjną.

Konsekwencją tego podejścia jest to, że modele kognitywistyczne są silnie intensjonalne, a więc ekstensjonalnie niezastępowalne. Modele ekstensjonalnie zastępowalne to takie, które dla takich samych danych wejścia zwracają takie same dane wyjścia.

Postulat o silnej intensjonalności (TI): Jeżeli w określonej dziedzinie modele kognitywistyczne A i B zwracają takie same dane wyjścia dla wszystkich danych wejścia, to nie jest tak, że jeżeli model A jest trafnym modelem czynności kognitywnej, to model $B$ jest nim również.

Odrzucenie postulatu o silnej intensjonalności prowadzi do behawioryzmu, w którym nie ma znaczenia sposób przetwarzania danych, czyli to, co się dzieje w umyśle kognitywnym. Jeżeli w wyniku modelowania procesu przyjmujemy, że mentalny korelat dla bodźca numerycznego ma charakter np. mereologiczny, a mechanizmy przetwarzania tych korelatów mają konkretne własności, np. nierekurencyjność, to nie możemy dowolnie wskazać innego ekstensjonalnie równoważnego modelu i wnioskować na jego podstawie czegokolwiek o modelu pierwotnym. Istotne jest to, co zachodzi w „czarnej skrzynce”. Zilustrujmy to przykładem. Dzieci do obliczenia wyniku mnożenia liczby jednocyfrowej przez 9 często stosują popularną heurystykę, posiłkując się palcami u obu dłoni. Kalkulator, aby policzyć to samo, przeprowadza operacje binarną. Wynik jest ten sam (modele są ekstensjonalnie wymienne). Nie można jednak twierdzić, że skoro możemy tak zaprogramować kalkulator, aby uzyskiwał podobne wyniki jak liczące dziecko, to znaczy, że dzieci liczą jak kalkulator, ponieważ przebieg tych obliczeń jest inny. Innymi słowy, interesuje nas nie tylko, jaki wynik zostanie zwrócony, ale jak przebiega proces jego osiągnięcia.

\section{Struktura modelu kognitywistycznego czynności numerycznych}

W przypadku modelowania kompetencji numerycznej zakładamy, że każdy uogólniony model jest dwuelementową strukturą $\langle\{S\}, M>$, gdzie $S$ jest mentalną strukturą arytmetyczną, natomiast $\mathrm{M}$ jest mechanizmem semantycznym.

Mentalna struktura arytmetyczna stanowi złożoną i uogólnioną reprezentację wartości numerycznych. Najprostszym przykładem mentalnej struktury arytmetycz- 
nej jest Mentalna Oś Liczbowa (mental number line) [Dehaene, 1997], której istnienie i własności zostały dość dobrze potwierdzone w ramach badań eksperymentalnych.

Rozmaite wyniki eksperymentalne pokazują, że nie posługujemy się jedną strukturą arytmetyczną [Seron, Pesenti, Noël, Deloche, Cornet, 1992]. Mentalna Oś Liczbowa dorosłych jest wyskalowana liniowo, tymczasem ta wykorzystywana przez dzieci - logarytmicznie. Dla dzieci mentalna odległość między liczbami maleje wraz ze wzrostem ich bezwzględnej wartości. Wraz z edukacją wykształcana jest liniowa reprezentacja osi, gdzie odległości między poszczególnymi liczbami są równe. Okazuje się jednak, że reprezentacje logarytmiczne nie zanikają i są również wykorzystywane przez dojrzałe liczące umysły [Banks, Coleman, 1981].

Oprócz reprezentacji liniowych wykorzystujemy na pewno także reprezentacje modularne. Najlepszy przykład to sposób odmierzania czasu. Nasza reprezentacja czasu dobowego jest kolista tak jak cyferblat zegara. Okazuje się, że w wyniku chorób, jak np. otępienia starczego czy choroby Alzheimera, ta konkretna reprezentacja może ulec uszkodzeniu [Krzymiński, 1995].

Konstruuje się też modele, $\mathrm{w}$ których reprezentacje mają strukturę wieloosiową [Krysztofiak, 2011]. W wyniku prowadzonych przez nas badań z zakresu modelowania procesów numerycznych próbujemy pokazać, że posiadamy również reprezentacje osiowe zapętlone czy parakonsystentne.

Złożoność mentalnej struktury arytmetycznej polega na tym, że sama składa się $\mathrm{z}$ innych reprezentacji, takich jak reprezentacje liczb czy działań arytmetycznych, a co więcej - organizuje te reprezentacje. Przyjmijmy, że mówimy o prostej reprezentacji mentalnej osi liczb naturalnych mniejszych od 10. Taka oś w istocie jest strukturą arytmetyczną z liniowym porządkiem na zbiorze liczb od 0 do 10 i standardowo rozumianymi operacjami arytmetycznymi. To, że dodając do 2 liczbę 3 , przesuwamy się o 3 „oczka” w prawo, a nie w lewo, i otrzymujemy znajdującą się tam 5 , a nie 8 , wynika z tego, że nasze reprezentacje „2”, „3”, „5” i „8” są dobrze zorganizowane.

To, że mentalna struktura arytmetyczna jest uogólniona, polega na tym, że reprezentacja ta jest obecna w każdym procesie numerycznym jako swego rodzaju „szablon”. Oznacza to, że zarówno w przypadku obliczania „2 + 2", jak i „3 3 +5” wykorzystywana jest ta sama reprezentacja mentalnej osi liczb. W trakcie procesu kognitywnego następuje aktywacja reprezentacji, a następnie interpretacja w kontekście poznawczym. Zobrazujmy to przykładem: jeżeli w danej sytuacji poznawczej aktywowane są tylko reprezentacje „2” i „,5”, to pośrednio uczestniczą w niej także reprezentacje „3" i „4" jako elementy reprezentacji uogólnionej. Innymi słowy, nie da się skutecznie dodać 3 do 5, mając jedynie reprezentacje „3”, „5”, „8”; potrzeba też reprezentacji liczb znajdujących się pomiędzy oraz reprezentacji operacji dodawania. Konsekwencją takiego poglądu jest to, że mentalna realizacja dodawania bardzo dużych liczb różni się od realizacji dodawania małych liczb, co znajduje potwierdzenie w występowaniu efektu wielkości [Moyer, Landauer, 1967].

Sama mentalna struktura arytmetyczna jednak nie wystarczy, aby wyjaśnić to, jak przeprowadzamy procesy numeryczne. Gdy szacujemy, dodajemy czy porządkujemy, zawsze odnosimy się do pewnej rzeczywistości pozareprezentacyjnej. W każdym konkretnym akcie kognitywnym liczymy coś. Innymi słowy, gdy dodajemy dwa jabłka do tych trzech, które już mamy w koszyku, potrzebujemy powiązać nasze ogólne mental- 
ne reprezentacje liczb 2 i 3 z fizycznymi jabłkami, a także operację dodawania z czynnością wkładania nowych jabłek do koszyka. Na głębszym poziomie poznawczym nasz umysł musi wykonać jeszcze więcej czynności: potraktować jabłka w koszyku i te dokładane jako osobne kolekcje, potraktować każde jabłko jako osobno enumerowane indywiduum, ograniczyć zasięg semantyczny pojęcia „jabłko” do aktualnego kontekstu. Mechanizmem semantycznym nazywamy więc ogół procesów interpretujących reprezentacje mentalne $\mathrm{w}$ rzeczywistości pozareprezentacyjnej, a więc zbiór funkcji reprezentacja $\rightarrow$ bodziec i bodziec $\rightarrow$ reprezentacja.

\section{Preliminaria metamatematyczne}

Pojęcie liczby naturalnej jest pierwotnym pojęciem arytmetyki dlatego, że nie definiuje się go za pomocą innych liczb. Podobnie na gruncie kognitywistyki myślenia matematycznego reprezentacje liczb naturalnych są reprezentacjami pierwotnymi, gdyż nie są złożone z innych reprezentacji. Obiegowa eksplikacja pojęcia liczby naturalnej mówi wprost, że są to liczby, za pomocą których liczymy i ustalamy porządki.

Elementarna teoria liczb naturalnych nazywana jest arytmetyką liczb naturalnych i jest teorią struktury:

$$
\mathrm{M}=<\mathrm{N}, \overline{+}, \overline{\times}, \overline{<}, \overline{0}, \overline{1}>
$$

gdzie $\mathrm{N}$ to zbiór elementów, $\mp, \bar{x}$ to binarne funkcje, dla których odpowiednio $\overline{0}, \overline{1}$ są elementami neutralnymi, a $\overline{<}$ jest relacją dyskretnie porządkującą zbiór $\mathrm{N}$. Struktura $\mathrm{M}$ jest więc dyskretnie uporządkowanym pierścieniem.

Arytmetyka nie powstała jednak po to, aby powiedzieć coś o klasie M-struktur, ale by powiedzieć coś o pewnej wyróżnionej M-strukturze, nazywanej modelem standardowym arytmetyki liczb naturalnych:

$$
\mathrm{S}=\langle\mathrm{N},+, \times,<, 0,1>
$$

gdzie $\mathrm{N}$ to zbiór kolejnych liczb $0,1,2 \ldots,+, \times$ to standardowo rozumiane i rekurencyjnie zdefiniowane funkcje dodawania i mnożenia, < to relacja bycia mniejszym-większym, a elementy wyróżnione to znane nam 0 i 1.

Próbę aksjomatyzacji arytmetyki liczb naturalnych jako pierwszy podjął Giuseppe Peano [Peano, 1967], udowadniając, że struktura M spełnia wszystkie sformułowane przez niego aksjomaty. Dlatego mówimy, że M jest modelem Arytmetyki Peano (PA).

Istnieją także inne struktury arytmetyczne, które są modelami PA. Przykład może stanowić struktura:

$$
\mathrm{M}_{1}=\langle\underline{\mathrm{N}}, \underline{ \pm}, \underline{\times}, \underline{\underline{0}}, \underline{1}>
$$

gdzie $\underline{\mathrm{N}}=\{0,2,4,6 \ldots\}, \underline{0}$ to $100, \mathrm{a} \pm$ zwiększa liczbę o $2 . \mathrm{M}_{1}$ też jest modelem PA i $\mathrm{M}_{1}$ $\neq$ S. Nietrudno jednak zauważyć, że $M_{1}$ i S są izomorficzne, a ich dziedziny posiadają 
ten sam typ porządkowy określany jako $\omega$ (gdzie $\omega$ to właśnie typ porządkowy zbioru liczb naturalnych).

Powyższego rozróżnienia możemy dokonać jedynie z poziomu metateorii. Z punktu widzenia PA nie jesteśmy w stanie odróżnić $S$ od $M_{1}$ ani od żadnej innej struktury, która jest modelem dla PA. Dlatego matematycy często mówią o wskazywaniu modelu z dokładnością do izomorfizmu, a więc o wskazywaniu klasy struktur izomorficznych. Trudności sprawia jednak to, że nie wszystkie struktury będące modelami PA są izomorficzne. Prostą konsekwencją twierdzenia o zwartości dla teorii pierwszego rzędu jest istnienie tzw. modeli niestandardowych, czyli struktur, które spełniają wszystkie aksjomaty teorii, ale nie są izomorficzne z modelami standardowymi. Konsekwencją jest to, że z poziomu PA nie jesteśmy w stanie wskazać, czy mamy do czynienia ze standardową czy niestandardową strukturą arytmetyczną.

Twierdzenie Skolema (TS): Istnieje przeliczalna struktura arytmetyczna M, taka, że $\mathrm{M}$ jest modelem PA i M jest nieizomorficzne $\mathrm{z}$ modelem standardowym [Skolem, 1971].

Skolem wykonał pierwszy krok w „ujarzmieniu” niestandardowych struktur arytmetycznych, udowadniając, że struktury te są przeliczalne, oraz podając sposób ich konstrukcji. Kolejnym krokiem było pokazanie, że struktury niestandardowe są strukturalnie podobne.

Twierdzenie Henkina (TH): Wszystkie przeliczalne niestandardowe struktury arytmetyczne mają typ porządkowy $\omega+\left(\omega^{*}+\omega\right) \times \eta$ (Henkin, 1950).

Typ porządkowy, o którym mowa w TH, możemy zilustrować następująco:

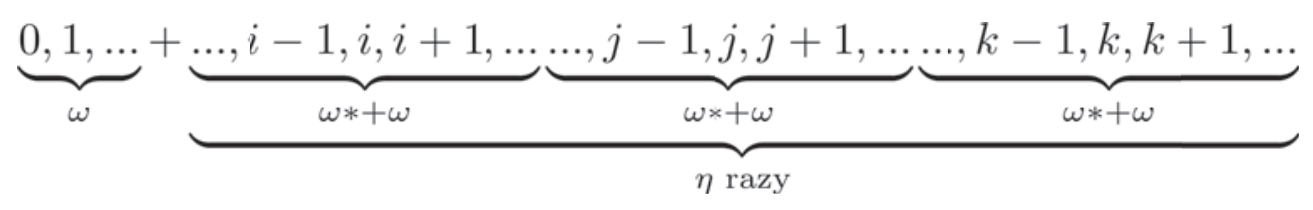

Ryc. 1. Schemat segmentów i typ porządkowy przeliczalnych niestandardowych struktur

Jak widzimy na rycinie 1, struktury te składają się z segmentów. Pierwszy segment o typie porządkowym $\omega$ to dziedzina standardowej struktury arytmetycznej, która jest segmentem początkowym każdej niestandardowej struktury (z uwagi na to, że struktury niestandardowe są elementarnym rozszerzeniem struktury standardowej). Dalej mamy powtórzony $\eta$ razy segment niestandardowy, gdzie $\eta$ to typ porządkowy zbioru liczb wymiernych. Segment niestandardowy składa się z trzech części: elementu niestandardowego $i$, elementów o typie porządkowym $\left(\omega^{\star}\right)$ poprzedzających element $i$ oraz elementów o typie porządkowym $(\omega)$ następujących po $i$.

Ważnym rezultatem ograniczającym program badania niestandardowych struktur arytmetycznych jest następujące twierdzenie limitacyjne udowodnione przez Tennenbauma: 
Twierdzenie Tennenbauma (TT): Niech $\mathrm{M}$ będzie przeliczalnym modelem PA, takim, że M nie jest izomorficzny względem modelu standardowego $\mathrm{S}$. Wtedy $\mathrm{M}$ jest nierekurencyjny [Kaye, 2006].

W dowodzie TT Tennenbaum za pomocą technik kodowania pokazał, że operacje arytmetyczne dodawania i mnożenia są rekurencyjne jedynie w standardowych strukturach arytmetycznych.

Wraz z rozwojem matematyki wykazano, że nie wszystkie problemy arytmetyczne można rozwiązać. Mówiąc wprost, nie wszystko da się policzyć. Matematycy, posługując się intuicyjnym pojęciem efektywnej obliczalności, poszukiwali kryterium demarkacyjnego pomiędzy obliczalnymi i nieobliczalnymi problemami. Trudność polega na tym, że pojęcie efektywnej obliczalności jest pozamatematyczne i niedefiniowalne w ramach żadnej sformalizowanej teorii. Próbą rozwiązania tego problemu jest Teza Churcha-Turinga:

Teza Churcha-Turinga (TCT): Funkcja f jest efektywnie obliczalna wtedy i tylko wtedy, gdy $\mathrm{f}$ jest rekurencyjna.

TCT utożsamia klasę funkcji efektywnie obliczalnych z pewną klasą funkcji posiadającą matematyczną własność rekurencyjności. Standardowo przyjmuje się, że TCT jest niedowodliwa, ponieważ nie można jej sformułować na gruncie żadnego systemu sformalizowanego. Wykorzystuje się ją natomiast, aby wyrazić intuicyjne pojęcie efektywnej obliczalności w ramach systemów formalnych za pomocą dobrze zdefiniowanego pojęcia rekursji. Funkcję nazywamy rekurencyjną wtedy, gdy: 1) zdefiniowana jest początkowa wartość, dla której określona jest wartość funkcji; 2) zdefiniowane są reguły pozwalające w przeliczanej liczbie kroków obliczyć wartość funkcji dla elementu $n$ na podstawie wartości funkcji dla elementu $n-1$.

\section{Efektywna obliczalność}

Modele niestandardowe teorii pierwszego rzędu rodzą poważną trudność. Formułując teorię formalną, chcemy $\mathrm{z}$ uwagi na pragmatyczne i badawcze cele opisać pewne konkretne struktury, nazywane modelami zamierzonymi. $\mathrm{Z}$ poziomu teorii nie jesteśmy jednak w stanie wskazać modelu zamierzonego. Dzieje się tak, ponieważ w ramach teorii nie potrafimy odróżnić struktur standardowych od niestandardowych. Możemy to zrobić dopiero w ramach teorii drugiego rzędu, które rozwiązując jedne problemy metamatematyczne, generują kolejne, tj. brak pełnej aksjomatyzacji dla teorii drugiego rzędu, brak twierdzenia o zwartości, nierozstrzygalność. Dlatego badacze próbują wskazywać na pewne metateoretyczne własności, które mogą pomóc $\mathrm{w}$ jednoznacznym określeniu modelu zamierzonego teorii.

Strukturaliści obliczeniowi wykorzystują Tezę Churcha-Turinga wraz z Twierdzeniem Tennenbauma, aby jednoznacznie wskazać na standardową strukturę arytmetyczną jako na model zamierzony PA [Halbach, Horsten, 2005; Zdanowski, Quinon, 2007]. Twierdzą oni, że model zamierzony PA służy przede wszystkim do liczenia, tak więc musi być on efektywnie obliczalny. 
Możemy zrekonstruować argumentację opartą na tej strategii w kontekście modelowania kognitywistycznego czynności numerycznych:

1. W modelu kognitywistycznym czynności numerycznych wszystkie mentalne operacje arytmetyczne muszą być efektywnie obliczalne.

2. Funkcja jest efektywnie obliczalna wtedy i tylko wtedy, gdy jest rekurencyjna (TCT).

3. Operacje arytmetyczne $\mathrm{w}$ strukturze arytmetycznej są rekurencyjne wtedy i tylko wtedy, gdy S jest standardową strukturą arytmetyczną (TT).

\section{Zatem:}

4. Jedynie standardowe struktury arytmetyczne mogą być składową modeli kognitywistycznych.

Konsekwencją przesłanek 1 i 2 jest następujący wniosek:

Wniosek: W modelu kognitywistycznym czynności numerycznych wszystkie mentalne operacje arytmetyczne muszą być rekurencyjne.

Opierając się na rozmaitych danych eksperymentalnych, będziemy wykazywać fałszywość tego wniosku. W efekcie, zakładając, że przesłanka (2) jest prawdziwa, a konsekwencja przesłanek (1) i (2) fałszywa, pokażemy, że przesłanka (1) jest fałszywa.

Będziemy bronić tezy:

Teza o nierekurencyjności (TN): Przynajmniej niektóre mentalne procesy numeryczne są nierekurencyjne.

\section{Badania empiryczne}

\section{Nierekurencyjne korelaty bodźców numerycznych}

Wachlarz rozmaitych czynności numerycznych obejmuje operowanie takimi liczebnikami jak: „wiele”, „około 3”, „kilka”, „mniej niż 4”. Skrajnym przypadkiem są systemy numeryczne plemion pierwotnych. Jako przykład mogą tutaj posłużyć członkowie plemienia Piraha zamieszkujący dorzecze Amazonii, których system numeryczny zawiera tylko trzy liczebniki: jeden, dwa i wiele [Gordon, 2004]. Co więcej, znaczenie tych liczebników wcale nie jest sztywno określone (jeden nie zawsze oznacza jeden). Należy podkreślić, że występowanie niedokładnych wielkości $\mathrm{w}$ procesach numerycznych nie jest problemem językowym. Nie chodzi o to, że odnosimy się w sposób nieostry lub wieloznaczny do dobrze określonych reprezentacji mentalnych, ale o to, że kodujemy niektóre bodźce ilościowe w sposób nieokreślony, niedokładny czy rozmyty. Nieostrość występuje na poziomie reprezentacji w umyśle, a nie języka.

Nie wiemy, w jaki sposób podmiot kognitywny koduje bodziec numeryczny „około 3". Jednym z możliwych rozwiązań jest zakodowanie go za pomocą pojedynczego niedokładnego korelatu. Inna możliwość to zakodowanie bodźca „około 3” jako 
obszaru mereologicznego zamiast punktu. Jeszcze inna możliwość to rozmyty zbiór liczb.

Trudno jest sformułować rekurencyjne reguły definiowania niedokładnych liczności. Czy w wyniku zastosowania do liczności „około 3” klasycznej funkcji następnika otrzymamy 4, „około 4”, a może wciąż „około 3"? Nie ma prostej odpowiedzi na to pytanie; czasami będzie to „około 3”, a czasami 4. Jest to zależne od kontekstu poznawczego, a więc od czynników niepodlegających rekursji. Nie da się także sformułować rekurencyjnych zasad rządzących tworzeniem i przetwarzaniem niedokładnych reprezentacji ilościowych. Nie dysponujemy ani rekurencyjną metodą konstrukcji takich reprezentacji, ani ich porównywania, redukowania, dodawania czy mnożenia.

Dlatego jako pierwsze do katalogu nierekurencyjnych czynności numerycznych zaliczymy czynności numeryczne, w których występują niedokładne reprezentacje ilościowe: szacowanie, arytmetyka plemion pierwotnych czy wreszcie codzienna praktyka numeryczna zawierająca liczebniki niedokładne / kwantyfikatory ilościowe.

\section{Nierekurencyjny charakter reprezentacji}

Na przebieg procesów numerycznych znamienny wpływ ma wiele rozmaitych modyfikatorów. Jednymi z nich są wartość bezwzględna liczby oraz wartość różnicy pomiędzy dwoma liczbami. Przy zadaniach związanych z porównywaniem wielkości liczb czas reakcji i liczba błędów wzrasta wraz ze wzrostem wartości liczb (efekt wielkości), natomiast zmniejsza się wraz ze wzrostem różnicy między porównywanymi liczbami (efekt dystansu) [Moyer, Landauer, 1967]. Innymi słowy, łatwiej nam się operuje na mniejszych liczbach i na dalej od siebie oddalonych.

Powyższe badania pokazują, że czas realizacji ludzkich procesów numerycznych jest wrażliwy na dane wejścia w sposób niezwiązany z rekurencyjnością. Rozważmy efekt wielkości. Z punktu widzenia rekursji różnica między 1 a 2 jest taka sama jak między 91 a 92 - jest nią pojedyncza iteracja funkcji następnika, czyli ,jeden krok”. Tymczasem badania nad efektem wielkości pokazują, że mentalna różnica między 1 i 2 jest większa niż między 91 a 92, co ma przełożenie w czasach reakcji. Wniosek jest taki, że mentalna funkcja następnika nie jest tożsama z rekurencyjną funkcją następnika.

Rozważmy teraz efekt dystansu. Załóżmy, że porównujemy liczby $n$ i $m$, gdzie $n<m$, i uzyskujemy czas reakcji $x$, a liczba kroków rekurencyjnych między $n$ i $m$ wynosi $y$. Zwiększając $m$ o dowolną ilość, uzyskujemy zwiększenie liczby kroków rekurencyjnych $y$ i zmniejszenie czasu reakcji $x$. Im więcej dodamy do $m$, tym bardziej wzrośnie $y$ i spadnie $x$. Wniosek jest taki, że mentalny dystans pomiędzy reprezentacjami liczb nie jest tożsamy $\mathrm{z}$ „dystansem rekurencyjnym”, rozumianym jako ilość kroków rekurencyjnych potrzebnych do wykonania operacji.

Powyższe przykłady pokazują, że porównywanie przez podmiot kognitywny wielkości dwóch liczb nie przebiega w sposób rekurencyjny. Czy dotyczy to też innych czynności numerycznych? Badania dowodzą, że tak. Łatwiej i szybciej dodajemy liczby małe niż duże [LeFevre, Sadesky, Bisanz, 1996]. Siła efektów wielkości i dystansu w czynnościach numerycznych dwuargumentowych wskazuje, że najprawdopodobniej żadna z nich nie jest rekurencyjna. 


\section{Nierekurencyjna praktyka liczeniowa}

Jakie właściwie argumenty mamy na poparcie tezy, że skoro operacja mnożenia jest rekurencyjna, to mentalny przebieg mnożenia również jest rekurencyjny? Założenie a priori takiego „podobieństwa” to tak jak założenie, że skoro budynek ma 100 metrów, to nasza mentalna reprezentacja tego budynku też ma 100 metrów i była budowana przez ekipę budowlaną przez rok.

Zarówno bezpośrednie opisy fenomenologiczne, jak i pomiary czasu reakcji odrzucają tezę, jakoby nasze mentalne obliczenia były rekurencyjne. Można wskazać rozmaite przykłady, w których podmiot kognitywny wykorzystuje rozmaite heurystyki czy zależności asocjacyjne, aby jak najłatwiej znaleźć wynik działania. Przykładowo podmiot kognitywny poproszony o obliczenie „100 + 100” doda jedynie wartości setne, a nie będzie wykonywać kolejnych kroków rekurencyjnego dodawania. Podobnie rzecz się ma w przypadku tabliczki mnożenia: podmiot kognitywny zapytany o to, ile to jest „6 $\times 6$ ”, nie podaje wyniku na podstawie pełnego procesu rekurencyjnego. Często wykorzystujemy też rozmaite korelacje liczbowo-nieliczbowe, np. wykonujemy obliczenia za pomocą palców czy przedmiotów. Techniki te widać w szczególności podczas rozwiązywania problemów z treścią. Można tutaj wskazać dwa przykłady. W pierwszym podmiot kognitywny proszony jest o rozwiązanie problemu „2 $2+3=$ ?”. Zamiast przeprowadzić faktyczne dodawanie, podmiot np. przy wykorzystaniu tzw. tokenów, a więc fizycznych reprezentacji wartości numerycznych, łączy obie kolekcje w jedno, po czym enumeruje liczność nowej kolekcji. W takiej sytuacji podmiot kognitywny nie przeprowadzi w ogóle arytmetycznego dodawania, a jedynie „wrzuci” tokeny na jeden stos i wykona czynność enumeracji nowo utworzonej kolekcji. Tak więc Jaś zapytany, ile to jest „2 jabłka +3 jabłka”, zamiast wykonać dodawanie arytmetyczne, położy wszystkie jabłka na stole i poprzez enumerację zliczy ich liczność.

Drugi przykład jest podobny. Rozważmy następujący problem z treścią: „Jest 5 dzieci i 3 jabłka. O ile więcej jest dzieci niż jabłek?”. Problem ten okazuje się trudny, jedynie $17 \%$ przedszkolaków i $64 \%$ pierwszoklasistów rozwiązuje go poprawnie [Cummins, Kintsch, Reusser, Weimer, 1988]. Okazuje się jednak, że jeśli sparafrazujemy problem następująco: „Jest 5 dzieci i 3 jabłka. Ile dzieci nie dostanie jabłek?”, to współczynnik rozwiązania wzrasta do 83\% wśród przedszkolaków i do 100\% wśród pierwszoklasistów [Hudson, 1983]. Zjawisko to tłumaczy się tym, że w drugim przypadku dzieci zamiast wykonywać faktyczne odejmowanie, ustaliły relację równoważnościową 1 - 1 między elementami kolekcji „dzieci” i „jabłka”, po czym dokonały enumeracji elementów bez pary. Przykład ten pokazuje, że działanie, które explicite jest sformułowane jako odejmowanie, może być realizowane w ogóle bez udziału arytmetyki. Co prowadzi do wniosku, że niektóre czynności numeryczne, które jawią się jako właściwe operacje arytmetyczne, niekoniecznie są nimi.

Należy w tym miejscu podkreślić, że istotne jest to, czy umysł ludzki realizuje dany proces numeryczny w sposób rekurencyjny, a nie czy można ten proces w jakiś sposób zrekonstruować za pomocą rekursji. Oczywiście można stwierdzić, że bezpośredni opis fenomenologiczny może nie być wiarygodny, a obliczenia na poziomie nieuświadomionym są wykonywane rekurencyjnie. Gdyby jednak tak było, to wykonanie obliczenia „1 1 1000" powinno mieć znacząco dłuższy czas realizacji niż „6 67 ” 
z uwagi na ilość kroków rekurencyjnych, podczas gdy jest dokładnie odwrotnie. Sposób wykonywania przez nas mnożenia nie jest rekurencyjny.

Wniosek jest taki, że nie tylko nie wykazano tego, iż wszystkie nasze mentalne operacje arytmetyczne mają charakter rekurencyjny, ale nawet prima facie jest wręcz odwrotnie.

\section{Dalsze kroki}

Dotychczas postawiliśmy i odpowiedzieliśmy twierdząco na pytanie: „Czy możemy dopuścić niestandardowe struktury arytmetyczne jako potencjalne składowe modeli kognitywistycznych zdolności numerycznych?". Naturalne jest to, aby zasygnalizować dalsze prace badawcze, stawiając pytanie: „Po co?”.

Unikatowe segmenty niestandardowych struktur, a także możliwe interakcje między nimi wprowadzają nowe możliwości modelowania. Liczby niestandardowe są nieosiągalne względem standardowych z uwagi na funkcję następnika: wyliczając kolejne liczby standardowe, nigdy nie dojdziemy do liczb niestandardowych. Co więcej, elementy poszczególnych segmentów liczbowych są izolowane, a ich elementy nieosiągalne względem siebie poprzez funkcję następnika. Niestandardowe liczby pozwalają też na kodowanie kolekcji nieskończonych, a więc reprezentowanie nieskończenie dużych oraz nieskończenie małych wielkości za pomocą liczb.

Sądzimy, że dalsze badania nad elementarnymi, prymitywnymi i nietypowymi czynnościami numerycznymi ukażą praktyczne zastosowania niestandardowych struktur arytmetycznych w modelowaniu kognitywistycznym czynności numerycznych. Przykładem takich sytuacji mogą być rozmaite gry i zabawy licytacyjne, w szczególności dziecięce, gdzie podczas wykonywania ruchów dochodzi się do wielkości „nieskończoność”. Często inny uczestnik zabawy odpowiada na taki ruch „nieskończoność + 100 ". Z matematycznego punktu widzenia ten ruch jest bez sensu, ponieważ w wyniku iteracji funkcji następnika do nieskończoności nie można otrzymać większej liczności (nieskończoność $=$ nieskończoność +100 ). Tymczasem $\mathrm{w}$ wielu grach wydaje się to dopuszczalny ruch, a nawet jeżeli nie, to ruch ten wywołuje pewną reakcję: restrykcję („nie możesz tak”) lub kolejną odpowiedź licytacyjną („to nieskończoność +200 ”). Gdy gracz A wykonuje ruch „nieskończonośc”, a gracz B „nieskończoność + 100”, to reakcja gracza A jest inna, niż gdyby gracz B wykonał ruch „nieskończoność”, a więc z punktu widzenia pragmatyki gry są to różne ruchy. Przy założeniu, że zasady gry opierają się na prawdziwej arytmetyce mentalnej, a nie jedynie konwencjach użycia w grze, wskazuje to na istnienie wielu segmentów liczbowych. Warto podkreślić, że kluczowym elementem przykładu nie jest nieskończoność liczności, ale jej nieosiągalność. Aby to zobrazować przykładem, wyobraźmy sobie zakochanych licytujących się, kto kogo kocha mocniej. Gdy Romeo wyznaje: „Kocham cię najmocniej na świecie”, a Julia odpowiada mu: „A ja ciebie jeszcze mocniej”, występuje mechanizm, w którym przywołuje się wartość graniczną, by następnie przejść do iterowania po wartościach przekraczających tę granicę. Niestandardowe struktury arytmetyczne mogłyby stanowić punkt wyjścia do modelowania tych zjawisk, gdyż liczby niestandardowe są zawsze większe od największych liczb standardowych. Mamy „więcej niż najwięcej”, 
które zyskujemy nie poprzez prostą iterację funkcji następnika, lecz poprzez wykonanie przeskoku w osi liczbowej.

\section{Podsumowanie}

Naszym celem było wykazanie prawdziwości Tezy o nierekurencyjności, w konsekwencji czego nie może być tak, że zarówno przesłanka (1), jak i (2) z argumentacji strukturalistycznej są prawdziwe. W związku z tym, że przesłanka (2) to powszechnie uznawana za prawdziwą Teza Churcha-Turinga, uznajemy przesłankę (1) za fałszywą. Skoro nie wszystkie mentalne operacje numeryczne są rekurencyjne, to nie można $\mathrm{w}$ ten sposób odrzucić niestandardowych struktur arytmetycznych jako składowych modeli kognitywistycznych czynności numerycznych.

Sądzimy, że powiększenie skrzynki z narzędziami teoretycznymi o niestandardowe struktury arytmetyczne pozwoli nam modelować szersze spektrum zjawisk numerycznych, a także przeprowadzić eksperymenty, które mogłyby zidentyfikować nowe rodzaje takich zjawisk. Kwestię ich rzeczywistej użyteczności pozostawiamy jednak otwartą dla badaczy eksperymentalnych.

\section{BIBLIOGRAFIA}

Banks, W.P., Coleman, M.J. (1981). Two subjective scales of number. Perception \& Psychophysics, 29 (2), 95-105. http://doi.org/10.3758/BF03207272.

Busemeyer, J.R., Diederich, A. (2010). Cognitive Modeling. Thousand Oaks: Sage Publications.

Cummins, D.D., Kintsch, W., Reusser, K., Weimer, R. (1988). The role of understanding in solving word problems. Cognitive Psychology, 20 (4), 405-438. http://doi.org/10.1016/00100285(88)90011-4.

Dehaene, S. (1997). The Number Sense: How the Mind Creates Mathematics. New York: Oxford University Press.

Fodor, J.A. (1983). Modularity of Mind. Cambridge: MIT Press.

Gordon, P. (2004). Numerical cognition without words: evidence from Amazonia. Science, 306, 496-499. http://doi.org/10.1126/science.1094492.

Halbach, V., Horsten, L. (2005). Computational Structuralism. Philosophia Mathematica, 13 (2), 174-186.

Henkin, L. (1950). Completeness in the Theory of Types. The Journal of Symbolic Logic, 15 (2), 81-91.

Hudson, T. (1983). Correspondences and Numerical Differences between Disjoint Sets. Child Development, 54 (1), 84-90.

Kaye, R. (2006). Tennenbaum's Theorem for Models of Arithmetic, 1-13. Retrieved from http:// books.google.com/books?hl=en\&amp;lr=\&amp;id=xlaPcJnz4iYC\&amp;oi=fnd\&amp;pg=PA 66\&amp;dq=Tennenbaum's+Theorem+for+Models+of+Arithmetic\&amp;ots=Ad9n0ZH44h \&amp;sig=hM2BdCVfonBkOzYc9N_NONm0q9k.

Krysztofiak, W. (2011). Indexed Natural Numbers in Mind: A Formal Model of the Basic Mature Number Competence. Axiomathes.

Krzymiński, S. (1995). Test rysowania zegara. Postępy Psychiatrii i Neurologii, 4 (1(2)), 21-30. 
Lakoff, G., Núñez, R. (2000). Where Mathematics Comes From. New York: Basic Books.

LeFevre, J.-A., Sadesky, G.S., Bisanz, J. (1996). Selection of procedures in mental addition: Reassessing the problem size effect in adults. Journal of Experimental Psychology: Learning, Memory, and Cognition, 22 (1), 216-230. http://doi.org/10.1037/0278-7393.22.1.216.

Moyer, R., Landauer, T. (1967). Time required for judgements of numerical inequality. Nature, 215.

Peano, G. (1967). The Principles of Arithmetic. W: J. Van Heijenoort (ed.). From Frege to Godel: A Source Book in Mathematical Logic (pp. 83-97). Cambridge, MA: Harvard University Press.

Seron, X., Pesenti, M., Noël, M.P., Deloche, G., Cornet, J.A. (1992). Images of numbers, or "when 98 is upper left and 6 sky blue". Cognition, 44 (1-2), 159-196. http://doi.org/10.1016/00100277(92)90053-K.

Skolem, T. (1971). Peano's Axioms and Models of Arithmetic. W: L.E.J. Brouwer, E. Beth, A. Heyting (eds.), Studies in Logic and the Foundations of Mathematics. Amsterdam, London: North-Holland Publishing Company.

Sun, R. (2008). Introduction to Computational Cognitive Modeling What is Computational Cognitive Modeling? W: R. Sun (ed.). The Cambridge Handbook of Computation Psychology (pp. 1-36). Cambridge, New York: Cambridge University Press.

Zdanowski, K., Quinon, P. (2007). The Intended Model of Arithmetic: An Argument from Tennenbaum's Theorem. Computation and Logic in the Real World. 